$\begin{array}{ll} & \text { Etnográfica } \\ \text { etnográfica } & \text { Revista do Centro em Rede de Investigação em }\end{array}$

Antropologia

vol. $18(2) \mid 2014$

Vol. $18(2)$

\title{
Introduction: anthropology and the neoliberal agenda
}

Introdução: a antropologia e a agenda neoliberal

Jon P. Mitchell and Noel Dyck

\section{(2) OpenEdition}

Journals

Electronic version

URL: https://journals.openedition.org/etnografica/3637

DOI: 10.4000/etnografica.3637

ISSN: 2182-2891

\section{Publisher}

Centro em Rede de Investigação em Antropologia

Printed version

Date of publication: 1 June 2014

Number of pages: 233-236

ISSN: 0873-6561

\section{Electronic reference}

Jon P. Mitchell and Noel Dyck, "Introduction: anthropology and the neoliberal agenda", Etnográfica [Online], vol. 18 (2) | 2014, Online since 09 July 2014, connection on 10 February 2022. URL: http:// journals.openedition.org/etnografica/3637 ; DOI: https://doi.org/10.4000/etnografica.3637

\section{(c) (1) (8)}

Etnográfica is licensed under a Creative Commons Attribution-NonCommercial 4.0 International License. 


\section{Introduction: anthropology and the neoliberal agenda}

\section{Jon P. Mitchell and Noel Dyck}

This short introduction contextualises the three contributions to this special section. Globally, anthropologists are feeling the effects of the neoliberal restructuring of the university. Here we examine the new pressures on anthropological research, to transcend the boundaries of the discipline in particular ways - through forms of interdisciplinarity and/or a focus on the societal or economic impact of research.

KEYWORDS: research, neoliberalism, university, funding, impact, interdisciplinarity. Introdução: a antropologia e a agenda neoliberal - Esta breve introdução contextualiza os três artigos que compõem o dossiê. Os antropólogos estão a sentir, de uma forma geral, os efeitos da restruturação neoliberal da universidade. Analisamos aqui como a investigação em antropologia está a ser sujeita a novas pressões para que transcenda as fronteiras da disciplina de determinadas maneiras - através de certas modalidades de interdisciplinaridade e/ou de uma especial atenção ao impacto da investigação sobre a sociedade e a economia.

PALAVRAS-CHAVE: investigação, neoliberalismo, universidade, financiamento, impacto, interdisciplinaridade.

MITCHELL, Jon P. (j.p.mitchell@sussex.ac.uk) - Department of Anthropology, University of Sussex, UK.

DYCK, Noel (ndyck@sfu.ca) - Department of Sociology and Anthropology, Simon Fraser University, Canada. 
THIS SHORT COLLECTION OF ESSAYS ARISES FROM A WORKSHOP HELD at the 2012 meeting of the European Association of Social Anthropologists in Paris. Working under the title "Reshaping the Conditions of Anthropological Practice", the workshop aimed to examine constraints on contemporary anthropological research agendas. To safeguard against disciplinary insularity, a qualitative sociologist with extensive experience of working with anthropologists was invited to join the panel. It became clear that constraints across a range of contexts were framed by imperatives, even requirements, by the institutions within and with which anthropologists work - universities, funding agencies, governments - that anthropologists and other ethnographers cross disciplinary borders in particular kinds of ways.

The three papers collected here examine these imperatives in the context of what Shore has described as the neoliberal restructuring of the university (Shore 2009, 2010). This is a global phenomenon, though one within which the Anglophone Commonwealth universities appear to be at the vanguard. Whilst Shore has focused on these processes in New Zealand, here we examine the UK and Canada, presenting contrasting but related examples of neoliberal agendas shaping research agendas.

As Noel Dyck points out in his contribution, anthropologists have long engaged in research projects that take them beyond their disciplinary boundaries - collaborating both with colleagues, ideas, methodologies from other academic disciplines and with institutions, agencies, "users", outside the academy. We might recall Evans-Pritchard's (1962) entreaty to incorporate history into the anthropological research agenda, and his engagements with the British colonial authorities in respect of Sudan. What is new, though, is the extent to which such cross-border engagements are increasingly prescribed, as requirements for academic funding regimes and audit cultures.

Dyck's paper on Canadian border-crossings looks at the requirements for interdisciplinary research that are shaping research agendas towards academic collaborations. As well as pointing out that interdisciplinarity is not as new in anthropology as funders often assume, Dyck highlights the inherent difficulties - both intellectually and bureaucratically - of managing cross-disciplinary work. Interdisciplinary projects require extremely strong and flexible management, which is complex, onerous and time-consuming. In intellectual terms, the results often fall short of expectations, and the danger going forward - or perhaps we have already arrived there - is that interdisciplinarity becomes an end in itself: rewarded for its sheer existence, rather than what it produces. That this skeptical tone cuts against the grain of much utopian thinking in respect of interdisciplinary research merely demonstrates - as does Dyck - the extent to which the bureaucratization of a virtue rapidly transforms it into a hollow but, nonetheless, oppressive exercise. 
Jon Mitchell's, and Caroline Knowles and Roger Burrows' papers look at UK border-crossings, and the current requirement that UK researchers must now demonstrate the observable and measurable impact of their research outside the academic sphere - in broader society, economy, polity. As with interdisciplinarity, as Dyck's essay demonstrates, there is nothing new to anthropologists having an impact beyond the academy. Anthropologists and more than a few sociologists have been advocates for indigenous peoples, social and political commentators, expert witnesses, developers, cultural collaborators. The problem with requiring such impact is not only that it instrumentalizes ethnographic and other forms of research, but also that it shifts the epistemological balance of the discipline from induction to prescription, and with that threatens to make normative a discipline that by its very nature is rooted in pluri-normativity, however that is understood. It effectively skews our understanding of not only future and current research agendas, but also the past, as social scientists are increasingly required to justify what research they have done in terms of the impacts it has had.

As with interdisciplinarity, non-academic impact becomes an end or aim of research, and one of the criteria for accountability and audit. Interdisciplinarity and impact become measurable indices, with the focus drawn towards "how much" of each is present in research, rather than "what kind" of interdisciplinarity or impact. Whilst Knowles and Burrows focus on the impacts of this "metricization" on the working conditions of anthropologists and sociologists in UK universities, Mitchell's slightly playful paper looks at the implications of auditing impact by examining anthropological controversies as "impacts".

Tracking developments such as these necessitates balancing generalized depictions of the nature and technologies of neoliberal governance with an appreciation of the often-unexpected ways in which these have shaped academia and anthropology. Ironically, the interdisciplinarity now promoted so vigorously by some governments is driven by the originally unanticipated and now seldom acknowledged consequences of prior administrative initiatives. The hardening of boundaries between disciplines and departments within the academy during the post-war period reflected the pressure generated by the establishment of internal markets within academia for student numbers. Current policy-makers" explanations of "intransigent disciplinary practice" remain the product of their unreflexive visions of what they think universities ought to have looked like in the first place, rather than any reflection of what was then or is now really going on. Thus, the impacts of their predecessors' administrative "solutions" are blithely ignored in the move to assign responsibility for today's perceived "problems" to academics, who serve as convenient targets for contemporary policy-making.

As the technologies of neoliberal governance have expanded, we have seen an increased - perhaps generalized - global concern with quantifying the 
quality of research outputs. The latest chapter in this expansion - described by these papers - sees this quantification expanded out, to examine the qualitative "texture" of research, rather than its academic quality: the extent to which it evinces interdisciplinarity, or exhibits preferred types of impact. As a result, and perversely, the regimes of accountability and audit appear to be drawing anthropologists and other ethnographers away from our roots, which themselves often required interdisciplinarity and a concern with the lifeworlds and livelihoods of our informants.

We are, then, perhaps uniquely placed to forge a critique of these new forms of accountability, as we have inhabited a world in which interdisciplinarity and impact have been the inevitable consequences of our intellectual journeys. The difference is that we have been driven by a humanistic concern to understand peoples' lives, rather than quantify the impacts we have had upon them, and the extent to which we have engaged with disciplinary "others". Anthropologists and their partners in other disciplines have always crossed borders. Now we must account for border-crossings.

\section{REFERENCES}

EVANS-PRITCHARD, Edward E., 1962, "Anthropology and history", in Edward E. EvansPritchard, Essays in Social Anthropology. London, Faber and Faber, 46-65.

SHORE, Cris, 2009, "Beyond the multiversity: neoliberalism and the rise of the schizophrenic university", Social Anthropology, 18 (1): 15-29.

SHORE, Cris, 2010, "The reform of New Zealand's university system: after neoliberalism", Learning and Teaching in the Social Sciences, 3 (1): 1-31. 